\title{
Soil Erosion Estimation Using Remote Sensing Techniques in Wadi Yalamlam Basin, Saudi Arabia
}

\author{
Jarbou A. Bahrawi, ${ }^{1}$ Mohamed Elhag, ${ }^{1}$ Amal Y. Aldhebiani, ${ }^{2}$ Hanaa K. Galal, ${ }^{2,3}$ \\ Ahmad K. Hegazy, ${ }^{4}$ and Ebtisam Alghailani ${ }^{2}$ \\ ${ }^{1}$ Department of Hydrology and Water Resources Management, Faculty of Meteorology, Environment \& Arid Land Agriculture, \\ King Abdulaziz University, Jeddah 21589, Saudi Arabia \\ ${ }^{2}$ Biological Sciences Department, Faculty of Science, King Abdulaziz University, Jeddah 21589, Saudi Arabia \\ ${ }^{3}$ Botany Department, Faculty of Science, Assiut University, Assiut 71515, Egypt \\ ${ }^{4}$ Department of Botany and Microbiology, Faculty of Science, Cairo University, Giza 12613, Egypt
}

Correspondence should be addressed to Mohamed Elhag; melhag@kau.edu.sa

Received 11 October 2015; Revised 5 February 2016; Accepted 16 February 2016

Academic Editor: Jianxi Zhu

Copyright (C) 2016 Jarbou A. Bahrawi et al. This is an open access article distributed under the Creative Commons Attribution License, which permits unrestricted use, distribution, and reproduction in any medium, provided the original work is properly cited.

\begin{abstract}
Soil erosion is one of the major environmental problems in terms of soil degradation in Saudi Arabia. Soil erosion leads to significant on- and off-site impacts such as significant decrease in the productive capacity of the land and sedimentation. The key aspects influencing the quantity of soil erosion mainly rely on the vegetation cover, topography, soil type, and climate. This research studies the quantification of soil erosion under different levels of data availability in Wadi Yalamlam. Remote Sensing (RS) and Geographic Information Systems (GIS) techniques have been implemented for the assessment of the data, applying the Revised Universal Soil Loss Equation (RUSLE) for the calculation of the risk of erosion. Thirty-four soil samples were randomly selected for the calculation of the erodibility factor, based on calculating the $K$-factor values derived from soil property surfaces after interpolating soil sampling points. Soil erosion risk map was reclassified into five erosion risk classes and $19.3 \%$ of the Wadi Yalamlam is under very severe risk (37,740 ha). GIS and RS proved to be powerful instruments for mapping soil erosion risk, providing sufficient tools for the analytical part of this research. The mapping results certified the role of RUSLE as a decision support tool.
\end{abstract}

\section{Introduction}

Evaluating soil erosion risks is a difficult undertaking task due to several concurrent processes, which affects individually other multifaceted interactions and continues at amounts that vary in both time and space $[1,2]$. Since the 1960s and on, soil decision-makers and scientists have examined models for calculating soil loss from erosion by water from rainwater, a hill slope, or a minor catchment $[3,4]$. With the presence of GIS competencies, the efforts have been directed to be based on spatially distributed models simulating erosion dynamics and surface runoff of more complex and larger catchments $[5,6]$.

Several models have been developed and used for either research or operational purposes. Some of the most known soil erosion models are USLE (Universal Soil Loss Equation, 1965), EPIC (Erosion/Productivity Impact Calculator, 1984), EUROSEM (European Soil Erosion Model, 1993), RUSLE (Revised Universal Soil Loss Equation, 1997), Rill Grow (a model for rill initiation and development, 1998), SEMMED (Soil Erosion Model for Mediterranean Regions, 1999), EGEM (Ephemeral Gully Erosion Model, 1999), PESERA (Pan-European Soil Erosion Risk Assessment, 2003), and so forth.

Soil erosion models can be distinguished as mechanistic (or process based) when they simulate the physical erosion processes by specific formulas or empirical when they calculate erosion based on regression of soil loss based on the physical properties of land and climate features $[7,8]$. They also can be characterized as dynamic when 
the time is a contained parameter. Long-term models are based on accumulated temporal data while event-based models describe single events $[9,10]$.

The soil erosion estimation models are focused on the identification and quantification of the erosion processes and the controlling factors, resulting in the sequential erosion models development beginning with the universal erosion equation (USLE) realized by Wischmeier and Smith [11], followed by a modified equation (MUSLE) for the quantification of the alluvium resulting from erosion following each rainfall realized by Williams [12], and eventually computerized and more complex equation (RUSLE) developed by Renard et al. [13].

The most important climatic variable in soil erosion processes is rainfall erosivity, which is related to rainfall amount and rainfall intensity $[14,15]$. Soil erosion is relatively related to rainfall, partially because of the shedding power of raindrops falls on the soil surface and partially because of the involvement of rainwater to surface runoff $[16,17]$.

Plants vegetative cover in addition to crop residues reduces soil erosion potential, due to the fact that the vegetation cover protects and leads to slowing down surface runoff movement and enhancing surplus surface water infiltration [18-20]. Type, extent, and quantity of the vegetation cover are the limiting factors of soil erosion effectiveness [21, 22].

The main aim of this research is to quantify the soil erosion in Wadi Yalamlam through examining the soil erodibility $K$-factor under different levels of soil data availability using the RUSLE model.

\section{Materials and Methods}

2.1. Study Area. Wadi Yalamlam basin is located about $125 \mathrm{~km}$ southeast of Jeddah city and is bounded by latitudes $20^{\circ} 26^{\prime}$ and $21^{\circ} 8^{\prime} \mathrm{N}$ and longitudes $39^{\circ} 45^{\prime}$ and $40^{\circ} 29^{\prime} \mathrm{E}$ (Figure 1). Wadi Yalamlam basin drained large catchment area of about $180,000 \mathrm{hr}$. The basin boundary of the lower part is enlarged to include nearly all the flat area in the downstream part. Wadi Yalamlam basin is initiated from high elevation Hijaz escarpment with mean annual rainfall of about $140 \mathrm{~mm}$. The basin elevations greatly vary from upstream and downstream parts and range between $2850 \mathrm{~m}$ and $25 \mathrm{~m}$ (ASL), respectively. The main course of Wadi Yalamlam has crosscut the highly fractured granitoid, gabbroic, and metamorphic rocks until the coastal plain of the Red Sea. The upper and middle parts of Wadi Yalamlam basin are covered by intense natural vegetation. The lower part is covered mainly by quaternary deposits and sand dunes with small scattered highly altered granitoid and metamorphosed basaltic hills. Several basic dikes are recorded in the lower part of Wadi Yalamlam basin. The thickness of quaternary Wadi Yalamlam deposits increased in the lower part.

2.2. Methodological Framework. The methodology is implemented through several steps which led to the intermediate and the final results. Initially, the $C, R, P$, and LS factors were calculated in order to be included in the RUSLE formula. Then, the $K$-factor was estimated from the soil samples using the USDA nomograph [23]. Later, three interpolation methods (Radial Basis Functions (RBF), Inverse Distance Weighted (IDW), and Ordinary Kriging (OK)) were checked for their accuracy and the $K$-factor layer (thematic map) was created using the most accurate method. By multiplying the RUSLE factors calculated earlier $(C * R * P *$ LS) with the $k$-layers (thematic map), soil erosion risk thematic map was created. Finally, the erosion risk map was reclassified into five classes of risk. The mathematical expression of RUSLE is

$$
A=R * K * \mathrm{LS} * C * P,
$$

where $A$ is the average annual erosion rate $\left(\mathrm{tha}^{-1} \mathrm{yr}^{-1}\right) ; R$ is the rainfall erosivity ( $\left.\mathrm{MJ} \mathrm{mm} \mathrm{ha} \mathrm{m}^{-1} \mathrm{~h}^{-1} \mathrm{yr}^{-1}\right) ; K$ is the soil erodibility (thah ha ${ }^{-1} \mathrm{MJ}^{-1} \mathrm{~mm}^{-1}$ ); LS is slope length and slope steepness factor (dimensionless); $C$ is the correction coefficient for the effect of vegetation (dimensionless); and $P$ is the correction coefficient for the effect of erosion control measurements (dimensionless).

2.3. Data Description. Meteorological data, especially rainfall data for the last 10 years, were collected from two adjacent weather stations. The first weather station located in the upper stream of the Wadi (latitudes $21^{\circ} 48^{\prime} \mathrm{N}$ and longitudes $\left.40^{\circ} 55^{\prime} \mathrm{E}, 1454 \mathrm{~m} \mathrm{ASL}\right)$, and the second weather station located in the lower stream (latitudes $19^{\circ} 01^{\prime} \mathrm{N}$ and longitudes $41^{\circ} 88^{\prime} \mathrm{E}$, $350 \mathrm{~m}$ ASL). Thirty-four soil samples were collected from the entire designated study area with a minimum distance of $500 \mathrm{~m}$ between the samples locations to avoid data clumping (Figure 1). Soil samples were taken to $30 \mathrm{~cm}$ depth and followed stratified random sampling techniques [24]. Physical properties of the soil samples were identified using mechanical mesh with series of pore sizes. Identification of silt as well as clay fractions was carried out following Mitchell [25]. Digital Elevation Model (DEM) data were acquired from the Japanese-American satellite ASTER GDEM. The used DEM is validated by the provider and ASTER GDEM is highly accurate DEM covering all the land on earth with $30 \mathrm{~m}$ spatial resolution. Landsat 8 Operational Land Imager (OLI) scene was acquired in 16th of July, 2015. Landsat 8 consists of 9 multispectral bands of $30 \mathrm{~m}$ spatial resolution and two thermal bands of $100 \mathrm{~m}$ spatial resolution in addition to the panchromatic bands of $15 \mathrm{~m}$ spatial resolution. Two Full-Width-Half-Maximum (FWHM) bands of $654.6 \mu \mathrm{m}$ as red band and $864.7 \mu \mathrm{m}$ as infrared band were exercised to drive Normalized Difference Vegetation Index (NDVI).

\subsection{Generation of $R, K-, L S, C$, and $P$ Factors. Rainfall} erosivity factor $(R)$, estimation of the rainfall erosivity factor $(R)$, is highly based on annual rainfall $(\mathrm{mm})$, and when the annual rainfall is high, erosivity $(R)$ is also high. Estimation of the rainfall erosivity factor was based on the average of the annual rainfall data for twenty-four-year period provided by two meteorological stations in the area. Rainfall erosivity factor $(R)$ was estimated based on total kinetic energy $(E)$ and maximum intensity in 30 minutes $(I)$ in an average year's rain. Barfield et al. [26] condense several measures that have examined relationships between individual storm energies 


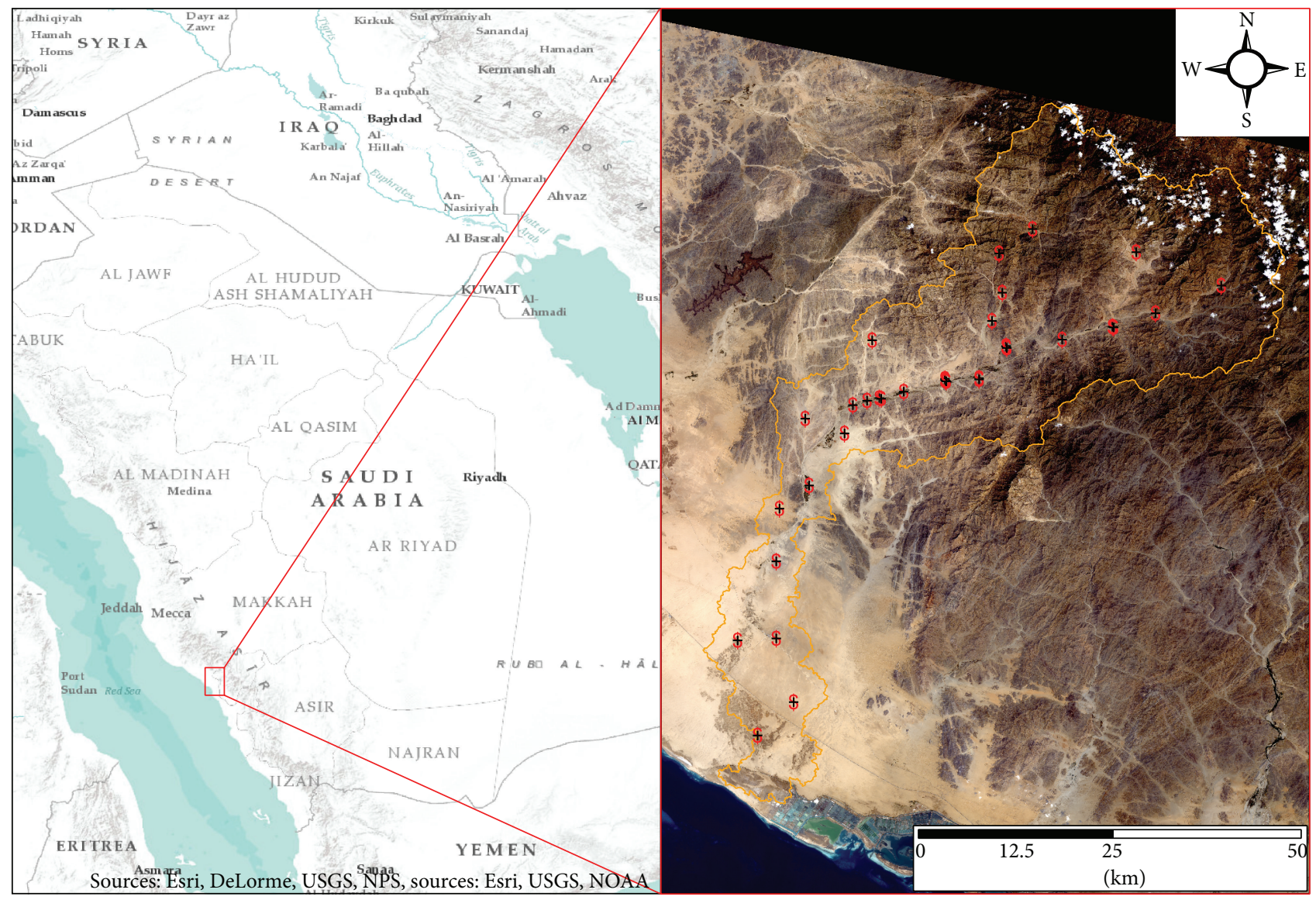

FIGURE 1: Location of the study including sample sites.

and erosion yields. According to Wischmeier [27], the best predictor of $R$ was

$$
R=\frac{1}{n} \sum_{j-1}^{n}\left[\sum_{k-1}^{m}(E)\left(I_{30}\right)_{k}\right]
$$

where $E$ is the total storm kinetic energy, $I_{30}$ is the maximum 30 -minute rainfall intensity, $j$ is the counter for each year used to produce the average, $k$ is the counter for the number of storms in a year, $m$ is the number of storms $n$ each year, and $n$ is the number of years used to obtain the average $R$.

Wischmeier [27] also found that the rain kinetic energy (E) could be predicted by

$$
E=916+(331) \log 10(I) .
$$

$K$-factor (soil erodibility) is the one that will be mainly examined. Using the stratified random sampling method, thirty-four points, randomly selected and stratified in regard to the geologic formations, were sampled for their necessary topsoil properties. Then, $K$ values were calculated according to the RUSLE formula for these methods following USDA monograph [23]. Finally, the $K$ values were interpolated to produce a surface of $K$ values for the total area. Not only is soil texture the principal component affecting $K$, but also soil permeability and soil organic content are essential. Rosewell and Loch [28] described a method to estimate $K$-factor. Soil physical analysis is indispensable in $K$-factor determination. Wischmeier and Smith [11] and Renard et al. [29] proposed an algebraic approximation taking into consideration five different soil features (soil organic content, soil permeability, soil texture, soil structure, and soil coarse fragments) as follows:

K

$=\left[\frac{\left(2.1 \times 10^{-4} M 1.14(12-\mathrm{OM})+3.25(s-2)+2.5(p-3)\right)}{100}\right]$

* 0.1317,

where $M$ is the textural factor with $M=\left(m_{\text {silt }}+m_{\mathrm{vfs}}\right) *(100-$ $\left.m_{\mathrm{c}}\right) ; m_{\mathrm{c}}[\%]$ is clay fraction content $(<0.002 \mathrm{~mm}) ; m_{\text {silt }}[\%]$ is silt fraction content $(0.002-0.05 \mathrm{~mm}) ; m_{\mathrm{vfs}}[\%]$ is very fine sand fraction content $(0.05-0.1 \mathrm{~mm})$; OM [\%] is the organic matter content; $s$ is the soil structure; and $p$ is the permeability class.

The slope factor (LS) refers to the topographic and/or the relief factor. The slope length factor L computes the effect of slope length on erosion and the slope steepness factor $\mathrm{S}$ computes the effect of slope steepness on erosion. The topography related parameters were derived from the Digital Elevation Model (DEM) following Wilson and Gallant 
[30]. Based on Wischmeier and Smith [11], LS values were estimated as follows:

$$
\mathrm{LS}=\left(\frac{\ell}{72.6}\right) m\left(65.41 \sin ^{2} \beta+4.56 \sin \beta+0.065\right),
$$

where $\ell$ is the cumulative slope length in feet; $\beta$ is the downhill slope angle; $m$ is a slope contingent variable, 0.5 if the slope angle is greater than $2.86^{\circ}, 0.4$ on slopes of $1.72^{\circ}$ to $2.86^{\circ}, 0.3$ on slopes of $0.57^{\circ}$ to $1.72^{\circ}$, and 0.2 on slopes less than $0.57^{\circ}$.

The cover management factor $(C)$ is dimensionless for each grid cell ranging from 0 to 1 under standard fallow conditions. As the surface cover is added to the soil, the $C$ factor value approaches zero. Generally, the $C$ factor is calculated based on derivation of Normalized Difference Vegetation Index (NDVI) and then reclassification of NDVI in order to extract the $C$ factor with higher positive values of NDVI. Red band and infrared band of Landsat 8 were exercised to estimate NDVI as follows:

$$
\mathrm{NDVI}=\frac{(I R-R)}{(I R+R)},
$$

where $I R$ is the infrared band and $R$ is the red band.

The support practice factor $(P)$ is defined as the ratio of soil loss with a specific support practice to the corresponding soil loss with up- and downcultivation. The lower the $P$ value is, the more effective the conservation practice is deemed to be in reducing soil erosion. Usually, in practice, expert opinion is used to qualitatively assess this factor.

Different interpolation techniques were used to produce adequate thematic maps based on the Root Mean Square Error (RMSE) evaluation. Principally, RBF shows better results rather than the other two interpolation methods in similar arid ecosystems [31]. This could be explained due to the fact that the RBF is considered as an exact interpolation technique, which means that the predicted values are identical to the measured values [32]. The interpolation is based on a mathematical function that smooths the generated surfaces by minimizing the surfaces curvature.

2.5. Integration of Factors for Erosion Risk Mapping. The erosion risk maps were generated by integrating all preestimated factors according to the RUSLE to create erosion map using $K$-factor values derived from soil sampling with interpolation. This was done using map algebra following the RUSLE method, where all layers generated previously were multiplied under GIS environment. The produced soil erosion map was consequently reclassified into five classes of erosion risk after Wischmeier and Smith [11].

\section{Results and Discussion}

In order to assess the soil erosion risks in the study area, several applications and analyses were implemented. Each generated factor was thus fully described and processed. From the available weather stations located in Wadi Yalamlam, regression was found between the mean annual precipitation 1983-2010 (mm/year) and the elevation to be read as

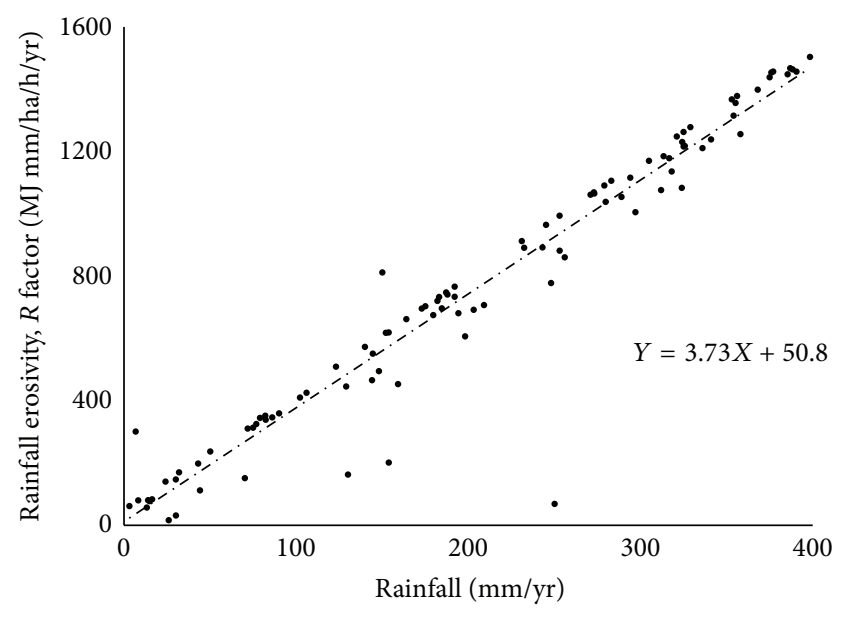

FIGURE 2: Rainfall erosivity factor versus yearly rainfall.

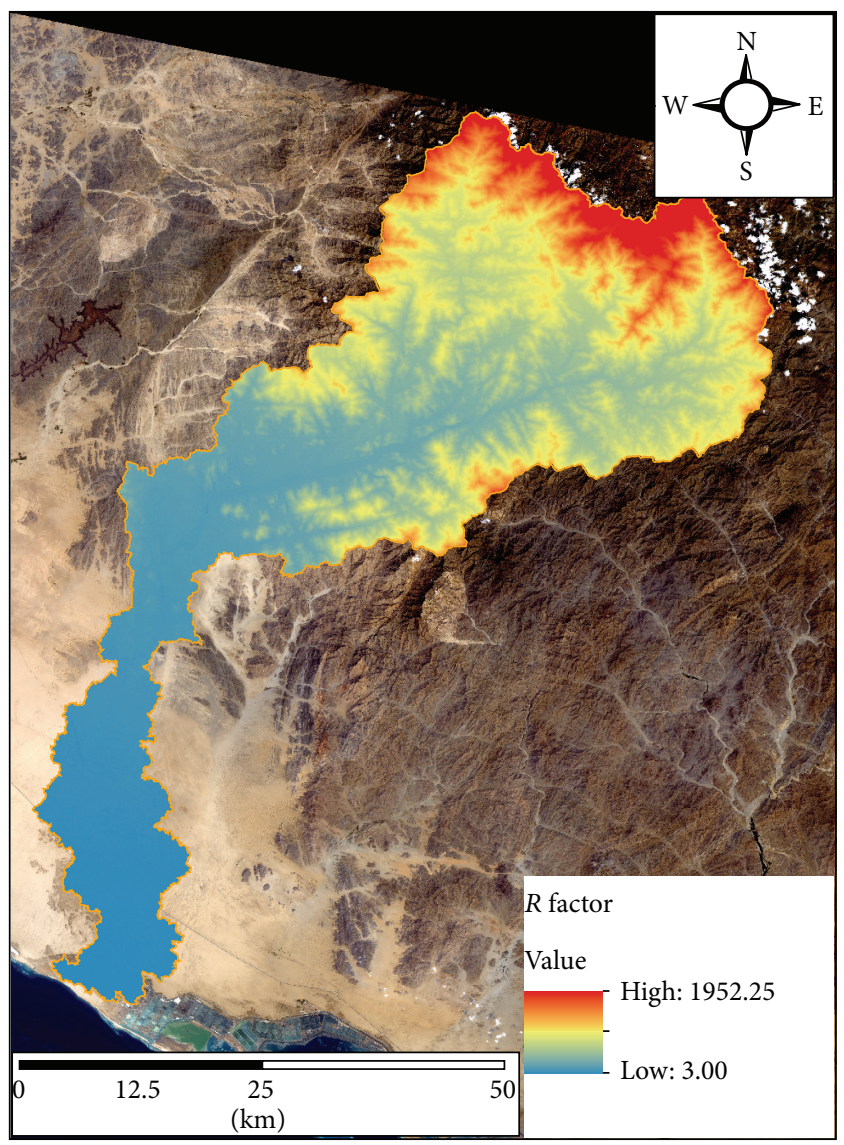

FIGURE 3: Thematic map of rainfall erosivity factor $(R)(\mathrm{MJ} \mathrm{mm} /$ ha year).

$P=3.73 * \mathrm{DEM}+50.8$ (Figure 2). The regression relationship was established before estimating the rainfall erosivity index as a function of average annual precipitation and elevation with $R^{2}$ of 0.967 . The final thematic map for rainfall erosivity factor is shown in Figure 3 . The standard error of estimate between the point and the surface $K$-factor is 0.005 tha hr/ha MJ mm; $K$-factor is with an acceptable 


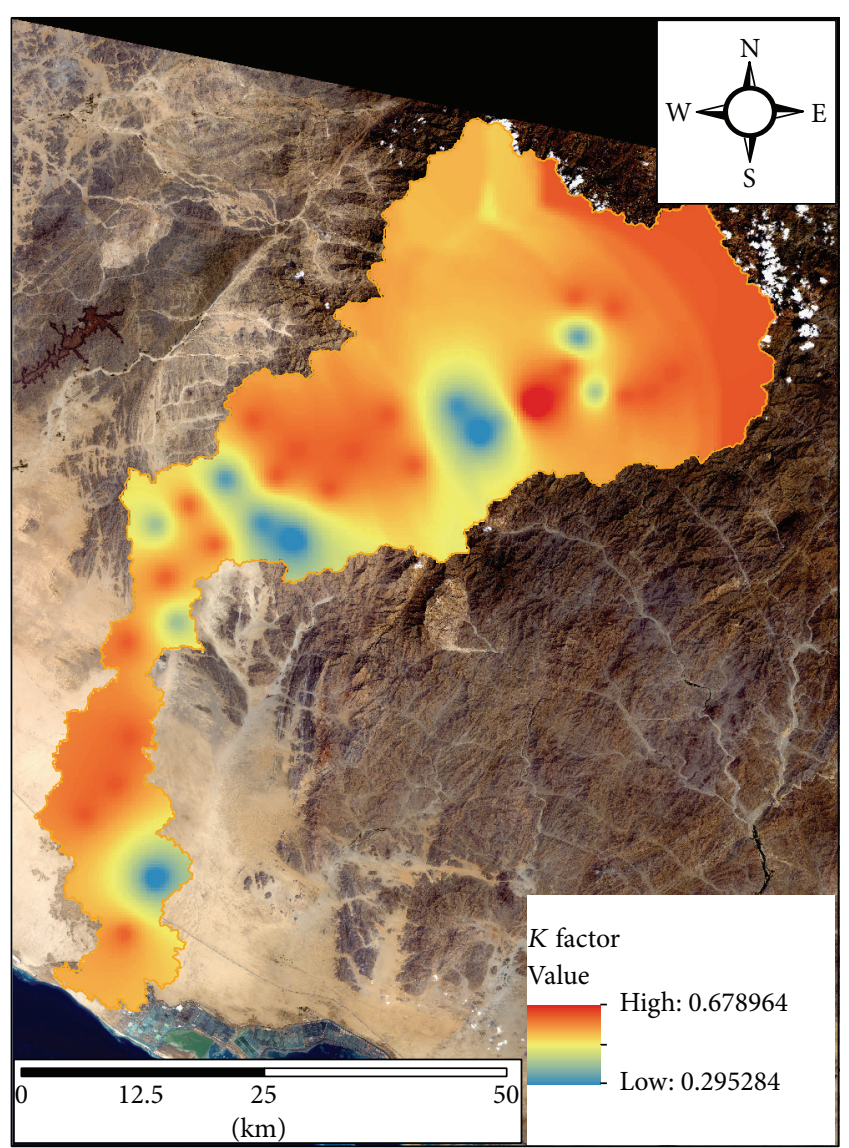

Figure 4: Thematic map of soil erodibility factor $(K)$ (tha hr/ ha MJ mm).

level of accuracy [33]. Thematic map for the soil erodibility factor is shown in Figure 4. To determine LS factor adjusted by Moore and Burch $[34,35]$ under GIS environment, the slope and flow length for each grid cell were estimated and illustrated in Figure 5. The effectiveness of the plant cover in reducing the raindrop impact depends on the height and the continuity of the canopy and the density of the ground cover. In this study, the $C$ factor was calculated using sigmoidal function derivation of Normalized Difference Vegetation Index (NDVI) to extract the $C$ factor.

The derivation of the NDVI values follows a monotonically decreasing sigmoid function with two control inflection points (0 and 1) which was used in order to define the fuzzy value of $C$ factor as illustrated in Figure 6. However, reclassification of the NDVI values was done in order to assign small values (near zero) for the $C$ factor for vegetated areas which are less risky in terms of erosion potential and big values (close to one) than sparsely vegetated areas and bare ground, which are more prone to erosion as it is shown in Figure 7.

The effect of terraces, contour planting (contouring), and tillage practices on soil erosion is described by the support practice factor $P$ within the RUSLE model. $P$ factor in Wadi Yalamlam is assumed to be 0.9. Such assumption is based on the fact that the wadi is with no agricultural practice in

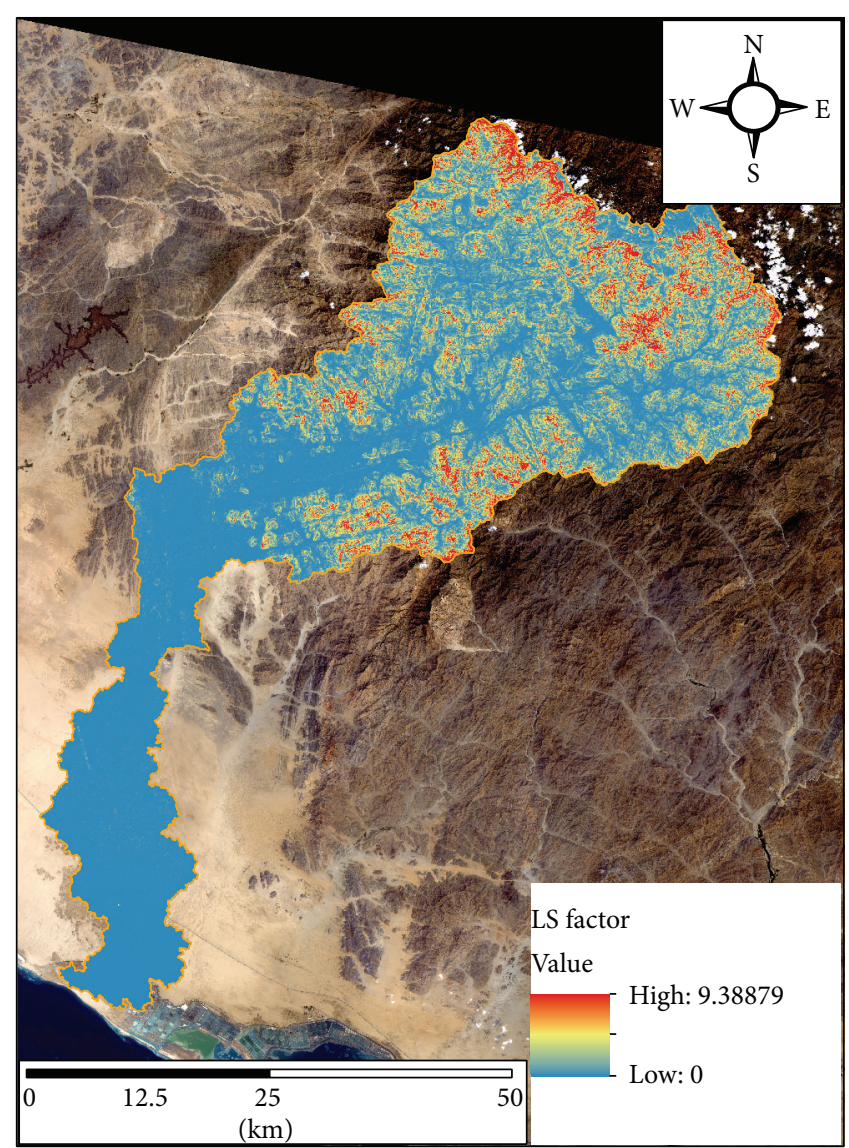

FIgURE 5: Thematic map of the length/slope (LS) factor.

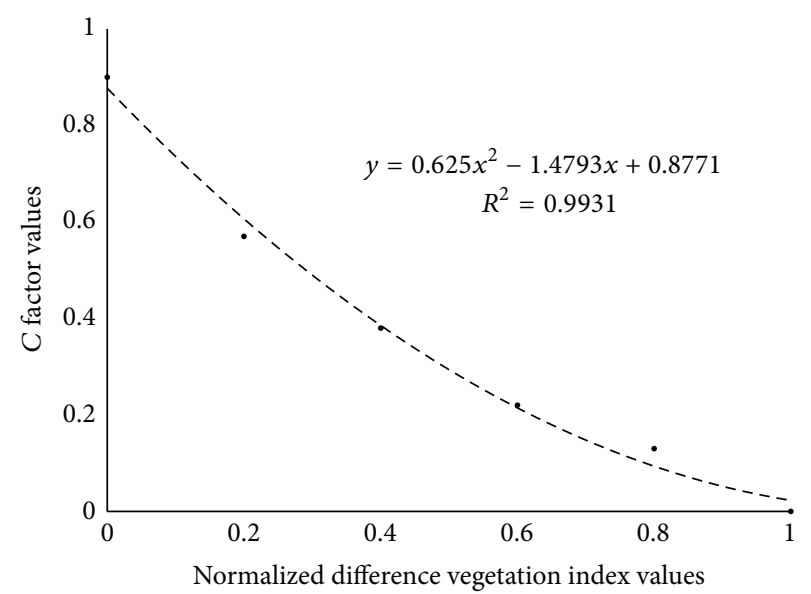

Figure 6: $C$ factor function versus Normalized Difference Vegetation Index.

the form of terraces and also the roads infrastructure as well as urban areas is disused due to its neglectability compared to the vast area of the wadi [36].

Standard normal distribution function practiced on the NDVI values indicated that most of the values are around zero value as demonstrated in Figure 8 . Several negative 
TABLE 1: Erosion risk classes (ERC) following Wischmeier and Smith [11].

\begin{tabular}{lccccc}
\hline Erosion class & ERC 1 & ERC 2 & ERC 3 & ERC 4 & ERC 5 \\
\hline Loss t/ha/year & $0-5$ & $5-10$ & $10-20$ & $20-40$ & Severe \\
Classification & Very slight & Slight & Moderate & Very severe \\
\hline
\end{tabular}

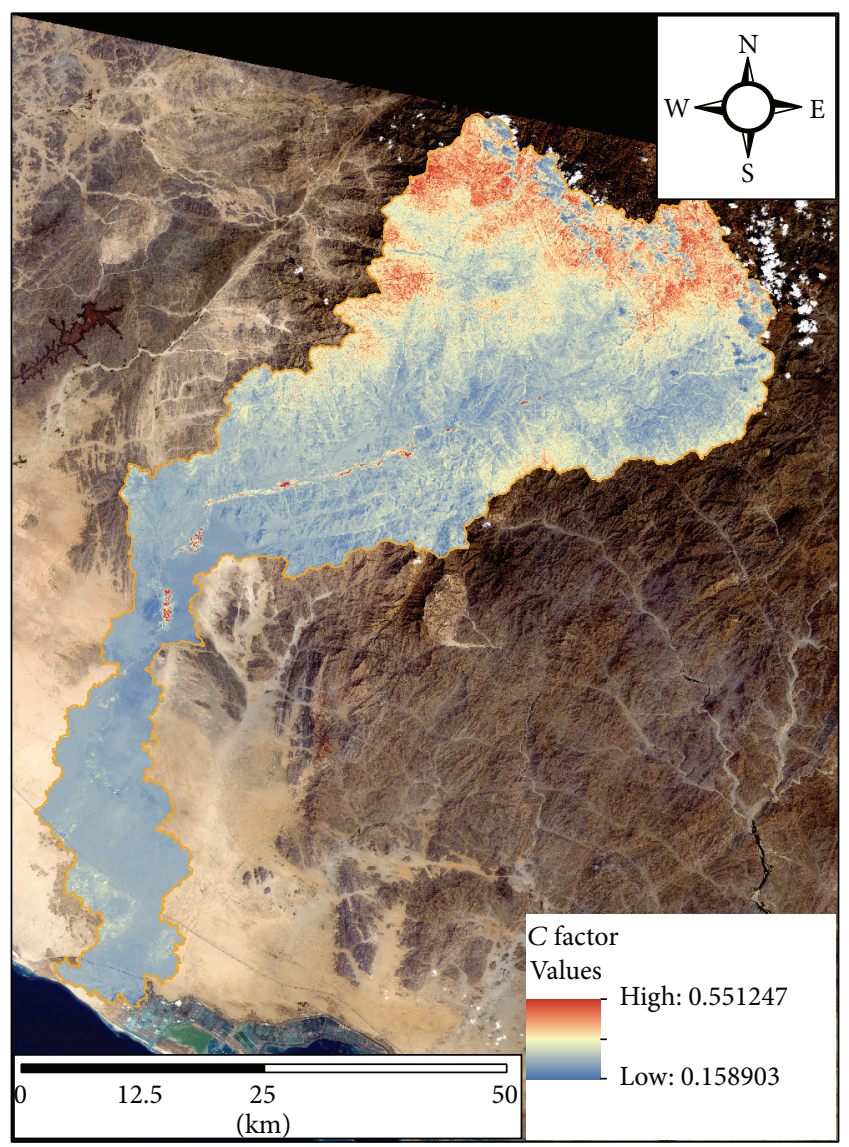

Figure 7: Thematic map of the $C$ factor.

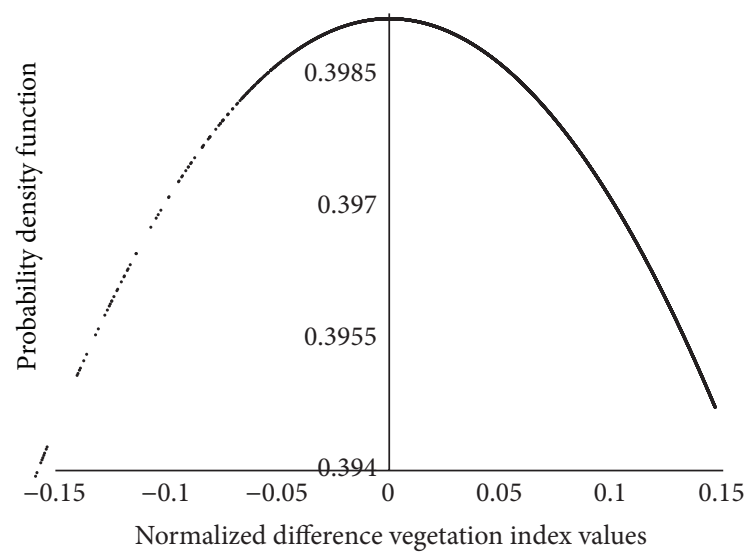

FIGURE 8: Standard normal distribution function of NDVI.

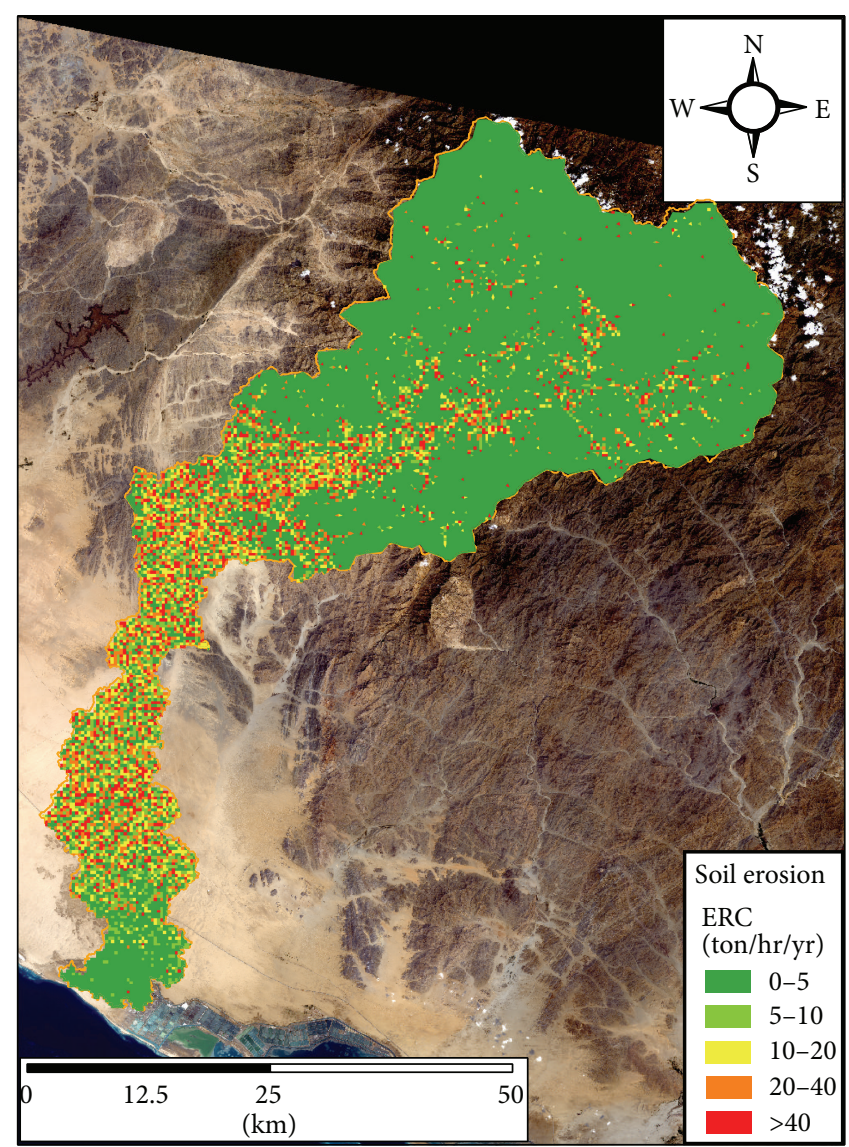

FIGURE 9: Soil erosion classification map.

values were reordered but there were more positive values indicating higher organic content [37].

The erosion risk map was generated by integrating all preestimated factors according to the RUSLE equation to create soil erosion map using $K$-factor values derived from soil sampling with interpolation of RBF with $R^{2}$ of 0.89 . This was done under map algebra toolbox to fulfill RUSLE method, where all layers generated previously were multiplied under GIS environment. Conducted soil erosion risk map was reclassified into five classes of erosion risk after Wischmeier and Smith [11], as showed in Table 1. The reclassified erosion risk map is shown in Figure 9. The upper part of the wadi, as well as the very lower part, is under the slight condition of erosion, which could be explained by the type of the bedrock material at the upper part and the no slope at the very lower part [38]. The narrow middle part of the wadi is under the very severe condition of soil erosion, which is logically 


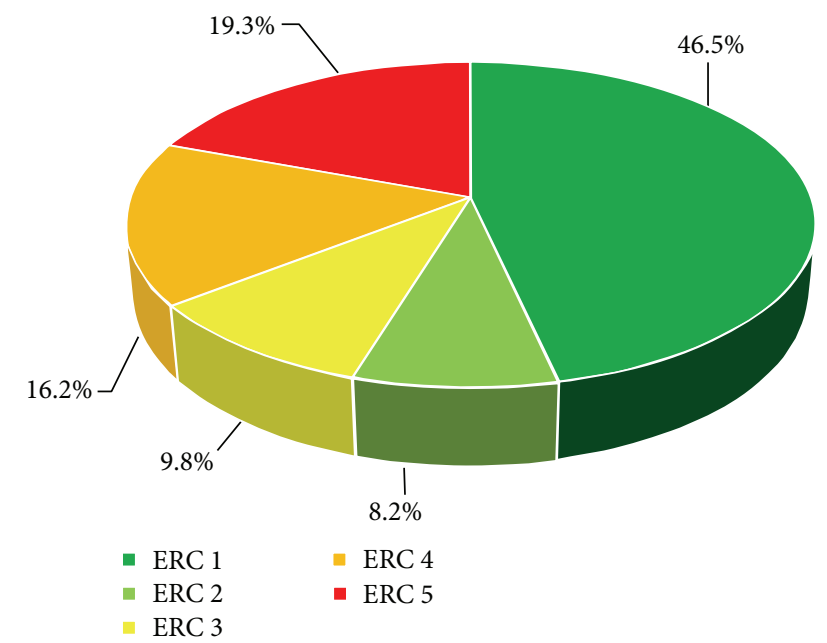

Figure 10: Area distribution of erosion risk classes using RUSLE model.

explained due to several geomorphological features including basically the drainage frequency $\left(F_{\mathrm{d}}\right)$, drainage density $\left(D_{\mathrm{d}}\right)$, and drainage texture $(\mathrm{T})$ of Wadi Yalamlam according to Elhag [37, 39, 40]. In addition, the stream network carves its course and it carries the sediment that erodes as it flows. This gives it more power to erode as there is more friction in the moving water, but it also deposits this material when it flows out of upper stream onto the lower stream [39].

Figure 10 demonstrates the proportion of each erosion risk class to the total basin area of Wadi Yalamlam. Nearly half of the total area is under slight risk (46.5\%). On the other hand, considerable areas are under very severe risk (19.3\%) and need further attention.

\section{Conclusion}

Erosion risk values are ranked into classes, which is in accordance with RUSLE standards as it provides better identification of the area most prone to erosion. The dissimilarities discovered earlier seem to fade out. Because the vast majority of erosion risk values in erosion risk map were bigger than 40 tons/ha/year, the reclassification of this map into categories of severity resulted in a concentration of values in the most severe category. Precaution measurements need to be set up in the middle part of Wadi Yalamlam as it is the most subjected parts to severe soil erosion. GIS and Remote Sensing are inevitable technological environments when implementing RUSLE for assessing soil erosion risk in the spatial domain. The adopted approach was based on mapping procedures, such as conversion of categorical into numerical polygons, interpolation of point samples, map algebra, and raster map reclassification. Data quality is a crucial parameter in soil erosion modeling and those errors and uncertainties are propagated to the final erosion results. Denser grid of sampling sites for the soil survey approach would produce a better $k$ layer after interpolation although such a procedure is costly and time-consuming.

\section{Competing Interests}

The authors declare that they have no competing interests.

\section{Acknowledgments}

This project was funded by the Deanship of Scientific Research (DSR) at King Abdulaziz University, Jeddah, under Grant no. (G-393-155-1436). The authors, therefore, acknowledge with thanks DSR for technical and financial support.

\section{References}

[1] P. M. Driesen, "Erosion hazards and conservation needs as a function of land characteristics and land qualities," in Land Evaluation for Land-Use Planning and Conservation in Sloping Areas, W. Siderius, Ed., pp. 32-39, ILRI, Wageningen, The Netherlands, 1986.

[2] C. Valentin, J. Poesen, and Y. Li, "Gully erosion: impacts, factors and control," Catena, vol. 63, no. 2-3, pp. 132-153, 2005.

[3] J. Wainwright, A. J. Parsons, and A. D. Abrahams, "Plot-scale studies of vegetation, overland flow and erosion interactions: case studies from Arizona and New Mexico," Hydrological Processes, vol. 14, no. 16-17, pp. 2921-2943, 2000.

[4] L. Turnbull, J. Wainwright, and R. E. Brazier, "Changes in hydrology and erosion over a transition from grassland to shrubland," Hydrological Processes, vol. 24, no. 4, pp. 393-414, 2010.

[5] E. G. Gregorich, K. J. Greer, D. W. Anderson, and B. C. Liang, "Carbon distribution and losses: erosion and deposition effects," Soil \& Tillage Research, vol. 47, no. 3-4, pp. 291-302, 1998.

[6] C. J. Williams, F. B. Pierson, P. R. Robichaud, and J. Boll, "Hydrologic and erosion responses to wildfire along the rangelandxeric forest continuum in the western US: a review and model of hydrologic vulnerability," International Journal of Wildland Fire, vol. 23, no. 2, pp. 155-172, 2014.

[7] M. V. K. Sivakumar, "Interactions between climate and desertification," Agricultural and Forest Meteorology, vol. 142, no. 2-4, pp. 143-155, 2007.

[8] I. Z. Gitas, K. Douros, C. Minakou, G. N. Silleos, and C. G. Karydas, "Multi-temporal soil erosion risk assessment in N. Chalkidiki using a modified USLE raster model," EARSeL eProceedings, vol. 8, no. 1, pp. 40-52, 2009.

[9] P. Podwojewski, J. L. Janeau, S. Grellier, C. Valentin, S. Lorentz, and V. Chaplot, "Influence of grass soil cover on water runoff and soil detachment under rainfall simulation in a sub-humid South African degraded rangeland," Earth Surface Processes and Landforms, vol. 36, no. 7, pp. 911-922, 2011.

[10] S. Grellier, J. Kemp, J.-L. Janeau et al., “The indirect impact of encroaching trees on gully extension: a 64 year study in a subhumid grassland of South Africa," Catena, vol. 98, pp. 110-119, 2012.

[11] W. H. Wischmeier and D. D. Smith, "Predicting rainfall erosion losses from cropland east of the Rocky Mountains," Agricultural Handbook 2828, US Government Print office, Washington, DC, USA, 1978.

[12] R. P. Williams, "Erosion and sediment transport in the Owens River near Bishop, California," Water-Resources Investigations Report 75-49, U. S. Geological Survey Water Resources Investigations, 1975. 
[13] K. Renard, G. R. Foster, G. A. Weesies, and J. P. Porter, "RUSLE revised universal soil loss equation," Journal of Soil and Water Conservation, vol. 46, pp. 30-33, 1991.

[14] E. Bochet and P. García-Fayos, "Factors controlling vegetation establishment and water erosion on motorway slopes in Valencia, Spain," Restoration Ecology, vol. 12, no. 2, pp. 166-174, 2004.

[15] V. H. D. Zuazo and C. R. R. Pleguezuelo, "Soil-erosion and runoff prevention by plant covers-a review," Agronomy for Sustainable Development, vol. 28, no. 1, pp. 65-86, 2008.

[16] G. Gyssels, J. Poesen, E. Bochet, and Y. Li, "Impact of plant roots on the resistance of soils to erosion by water: a review," Progress in Physical Geography, vol. 29, no. 2, pp. 189-217, 2005.

[17] S. Cohen, T. Svoray, J. B. Laronne, and Y. Alexandrov, "Fuzzybased dynamic soil erosion model (FuDSEM): modelling approach and preliminary evaluation," Journal of Hydrology, vol. 356, no. 1-2, pp. 185-198, 2008.

[18] V. H. D. Zuazo, J. R. F. Martínez, C. R. R. Pleguezuelo, A. M. Raya, and B. C. Rodríguez, "Soil-erosion and runoff prevention by plant covers in a mountainous area (SE Spain): implications for sustainable agriculture," Environmentalist, vol. 26, no. 4, pp. 309-319, 2006.

[19] P. K. Shit, G. S. Bhunia, and R. Maiti, "Assessing the performance of check dams to control rill-gully erosion: small catchment scale study," International Journal of Current Research, vol. 5, pp. 899-906, 2013.

[20] A. Psilovikos and M. Elhag, "Forecasting of remotely sensed daily evapotranspiration data over nile Delta region, Egypt," Water Resources Management, vol. 27, no. 12, pp. 4115-4130, 2013.

[21] V. M. Castillo, M. Martinez-Mena, and J. Albaladejo, "Runoff and soil loss response to vegetation removal in a semiarid environment," Soil Science Society of America Journal, vol. 61, no. 4, pp. 1116-1121, 1997.

[22] V. H. Durán Zuazo, J. R. F. Martínez, C. R. R. Pleguezuelo, A. Martínez Raya, and B. C. Rodríguez, "Soil-erosion and runoff prevention by plant covers in a mountainous area (SE Spain): implications for sustainable agriculture," Environmentalist, vol. 26, no. 4, pp. 309-319, 2006.

[23] USDA. Agricultural Research Service USDA-ARS, "CREAMS, a field scale model for chemicals, runoff, and erosion from agricultural management systems," Conservation Research Report 26, USDA, 1980.

[24] S. Lohr, Sampling: Design and Analysis, Duxbury, Pacific Grove, Calif, USA, 1999.

[25] J. K. Mitchell, Fundamentals of Soil Behavior, John Wiley \& Sons, New York, NY, USA, 1976.

[26] B. J. Barfield, R. C. Warner, and C. T. Haan, Applied Hydrology and Sedimentology for Disturbed Areas, Oklahoma Technical Press, Stillwater, Okla ,USA, 1983.

[27] W. H. Wischmeier, "A rainfall erosion index for a universal soilloss equationl," Soil Science Society of America Journal, vol. 23, no. 3, pp. 246-249, 1959.

[28] C. J. Rosewell and R. J. Loch, "Estimation of the RUSLE soil erodibility factor," in Soil Physical Measurement and Interpretation for Land Evaluation, N. McKenzie, K. Coughlan, and H. Cresswell, Eds., pp. 361-369, CSIRO Publishing, Melbourne, Australia, 2002.

[29] G. R. Renard, G. A. Foster, and D. K. Weessies, "McCool predicting soil erosion by water: a guide to conservation planning with the Revised Universal Soil Loss Equation (RUSLE)," in Agriculture Handbook, D. C. Yoder, Ed., p. 703, US Department of Agriculture, Washington, DC, USA, 1997.
[30] J. P. Wilson and J. C. Gallant, Terrain Analysis-Principles and Application, John Wiley \& Sons, New York, NY, USA, 2000.

[31] M. Elhag, "Evaluation of different soil salinity mapping using remote sensing techniques in arid ecosystems, Saudi Arabia," Journal of Sensors, vol. 2016, Article ID 7596175, 8 pages, 2016.

[32] N. Nikolova and S. Vassilev, "Mapping precipitation variability using different interpolation methods," in Proceedings of the Conference on Water Observation and Information System for Decision Support (BALWOIS '06), Ohrid, Macedonia, May 2006.

[33] W. Drzewiecki, P. Wezyk, M. Pierzchalski, and B. Szafrańska, "Quantitative and qualitative assessment of soil erosion risk in Małopolska (Poland), supported by an object-based analysis of high-resolution satellite images," Pure and Applied Geophysics, vol. 171, no. 6, pp. 867-895, 2014.

[34] I. D. Moore and G. J. Burch, "Physical basis of the length-slope factor in the universal soil loss equation," Soil Science Society of America Journal, vol. 50, no. 5, pp. 1294-1298, 1986.

[35] I. D. Moore and G. J. Burch, "Modelling erosion and deposition: topographic effects," Transactions of the American Society of Agriculture Engineers, vol. 29, no. 6, pp. 1624-1630, 1986.

[36] T. Chen, R.-Q. Niu, P.-X. Li, L.-P. Zhang, and B. Du, "Regional soil erosion risk mapping using RUSLE, GIS, and remote sensing: a case study in Miyun Watershed, North China," Environmental Earth Sciences, vol. 63, no. 3, pp. 533-541, 2011.

[37] M. Elhag, "Remotely sensed vegetation indices and spatial decision support system for better water consumption regime in Nile Delta. A case study for rice cultivation suitability map," Life Science Journal, vol. 11, no. 1, pp. 201-209, 2014.

[38] K. H. Al-Zahrani and M. B. Baig, "Water in the kingdom of Saudi Arabia: sustainable management options," Journal of Animal and Plant Sciences, vol. 21, no. 3, pp. 601-604, 2011.

[39] M. Elhag, "Characterization of a typical mediterranean watershed using remote sensing techniques and GIS tools," Hydrology: Current Research, vol. 6, no. 1, pp. 197-204, 2015.

[40] M. Elhag and J. A. Bahrawi, "Conservational use of remote sensing techniques for a novel rainwater harvesting in arid environment," Environmental Earth Sciences, vol. 72, no. 12, pp. 4995-5005, 2014. 

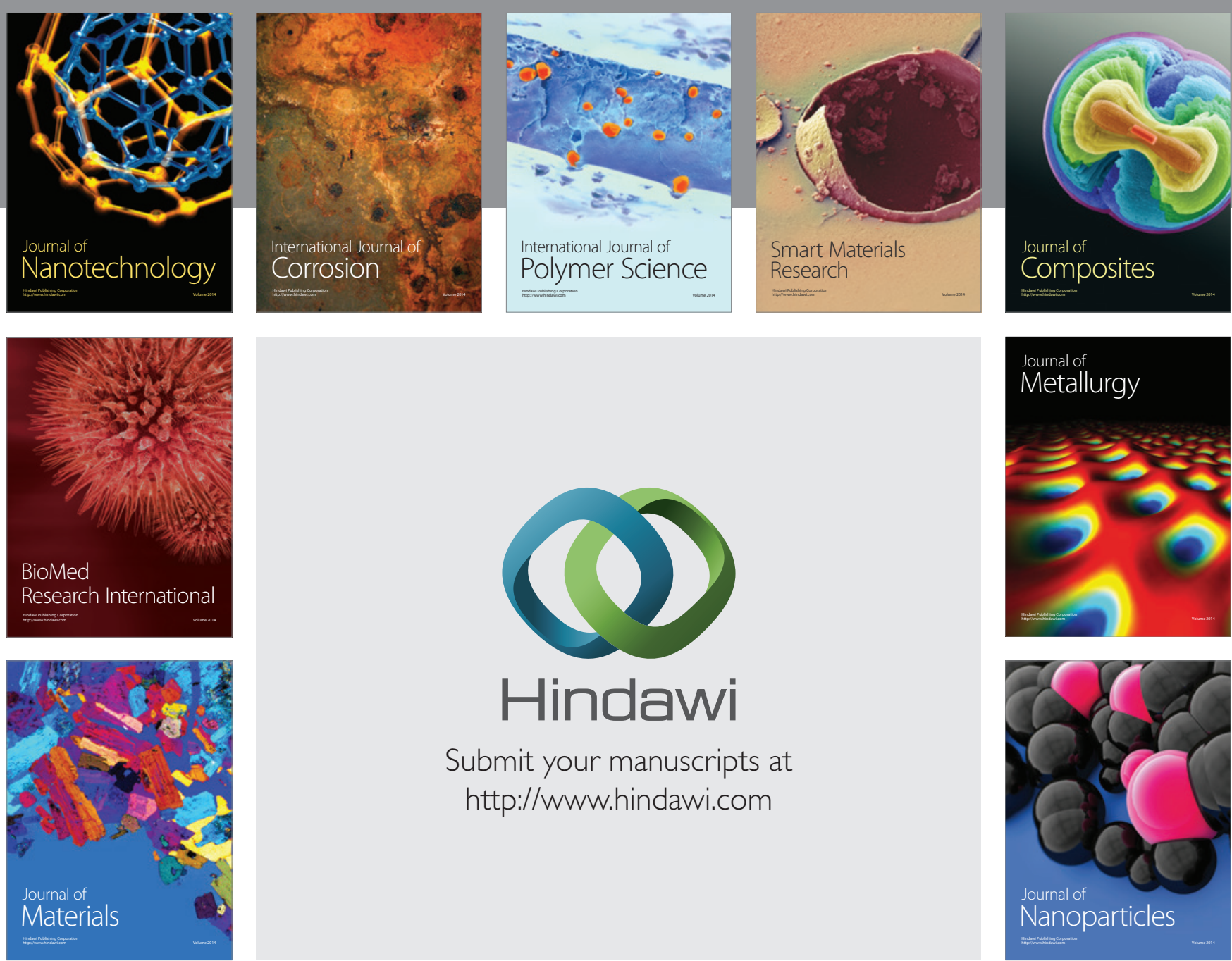

\section{Hindawi}

Submit your manuscripts at

http://www.hindawi.com

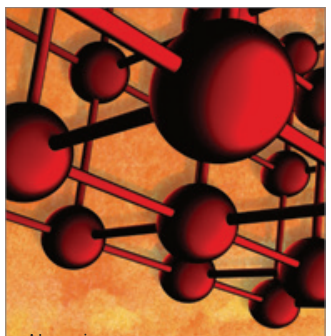

Materials Science and Engineering
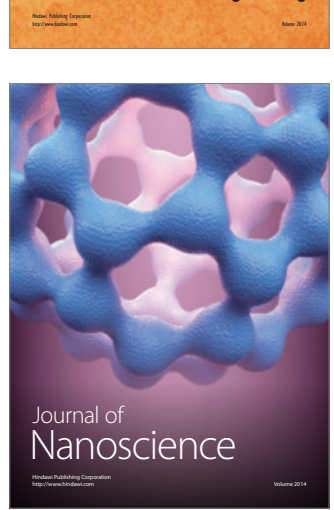
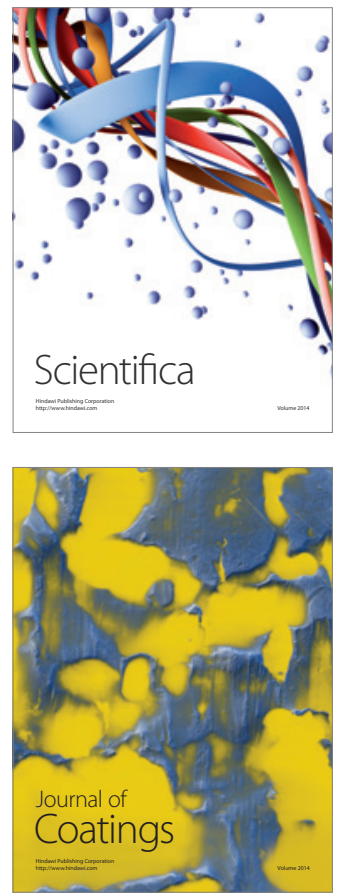
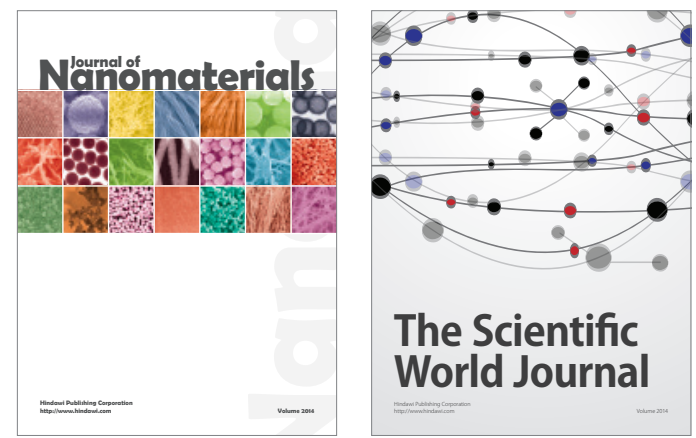

The Scientific World Journal
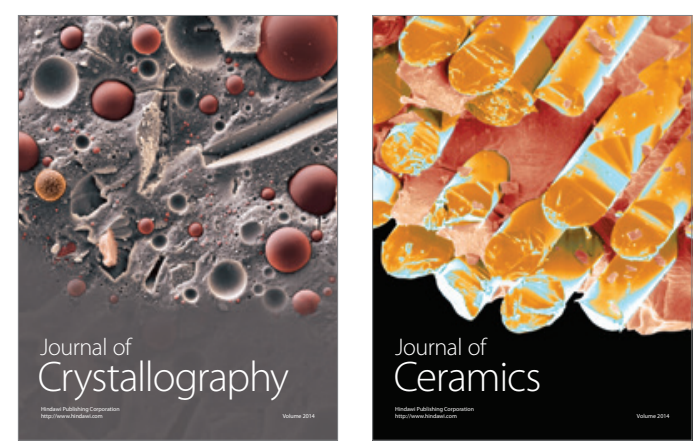
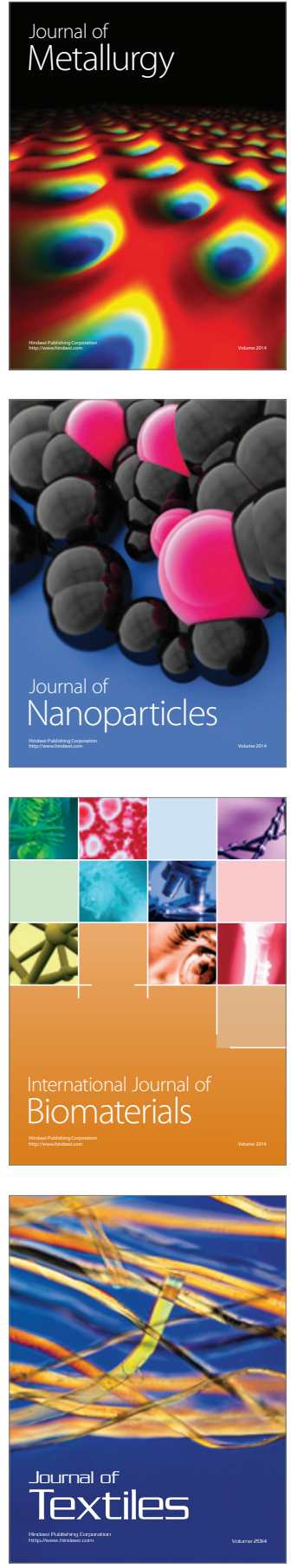